\title{
Psychrobacter cryohalolentis sp. nov. and Psychrobacter arcticus sp. nov., isolated from Siberian permafrost
}

\author{
Corien Bakermans, ${ }^{1}$ Héctor L. Ayala-del-Río, ${ }^{1,2}$ Monica A. Ponder, ${ }^{1}$ \\ Tatiana Vishnivetskaya, ${ }^{3}$ David Gilichinsky, ${ }^{4}$ Michael F. Thomashow ${ }^{1}$ \\ and James M. Tiedje ${ }^{1}$ \\ ${ }^{1}$ Center for Microbial Ecology and NASA Astrobiology Institute, Michigan State University, \\ East Lansing, MI 48824, USA \\ ${ }^{2}$ Department of Biology, University of Puerto Rico at Humacao, Humacao, PR 00791, \\ Puerto Rico \\ ${ }^{3}$ Department of Food Science, North Carolina State University, Raleigh, NC 27695, USA \\ ${ }^{4}$ Institute of Physico-chemical and Biological Problems in Soil Science, Russian Academy of \\ Sciences, 142290 Pushchino, Moscow Region, Russian Federation
}

Correspondence

Corien Bakermans bakerm16@msu.edu

\begin{abstract}
Three Gram-negative, non-motile, non-pigmented, oxidase-positive coccobacilli capable of growth at temperatures from -10 to $30{ }^{\circ} \mathrm{C}$ and salinities of 0 to $1.7 \mathrm{M} \mathrm{NaCl}$ were isolated from Siberian permafrost and characterized. Both 16S rRNA and gyrB gene sequencing studies placed the isolates in the Gammaproteobacteria within the genus Psychrobacter. However, with higher bootstrap values and reproducible tree topologies, gyrB represented a more reliable phylogenetic marker for the taxonomy of Psychrobacter species. DNA-DNA hybridization data supported gyrB tree topologies and established two relatedness groups within the three isolates; neither of these groups was related at the species level to any previously described Psychrobacter species. The two groups of isolates could be differentiated phenotypically from 13 previously described Psychrobacter species using API strips. These results support the existence of two novel species of Psychrobacter, for which we propose the names Psychrobacter cryohalolentis sp. nov.

(type strain $\mathrm{K}^{\top}=\mathrm{DSM} 17306^{\top}=\mathrm{VKM} \mathrm{B}-2378^{\top}$ ) and Psychrobacter arcticus sp. nov. (type strain $273-4^{\top}=$ DSM $17307^{\top}=$ VKM B $\left.-2377^{\top}\right)$.
\end{abstract}

The genus Psychrobacter comprises psychrophilic to psychrotolerant, halotolerant, aerobic, non-motile, Gramnegative coccobacilli and was first described as a genus separate from Acinetobacter in 1986 (Bowman, 2005; Juni \& Heym, 1986). Known Psychrobacter species are capable of reproduction at temperatures ranging from -10 to $37^{\circ} \mathrm{C}$. Examples range from the strict (stenothermal) psychrophile Psychrobacter frigidicola ( 0 to $22^{\circ} \mathrm{C}, T_{\text {opt }}=15^{\circ} \mathrm{C}$ ) to the eurythermal psychrophile Psychrobacter okhotskensis ( -5 to $35^{\circ} \mathrm{C}, T_{\text {opt }}=25^{\circ} \mathrm{C}$ ). While Psychrobacter species are coldadapted, other distinguishing characteristics include salt tolerance, natural competence and cellular fatty acid content (Juni \& Heym, 1986; Moss et al., 1988). Psychrobacter species have been isolated from a variety of low-temperature

Abbreviations: ANI, average nucleotide identity; PLFA, phospholipid fatty acid.

The GenBank/EMBL/DDBJ accession numbers for the 16S rRNA gene sequences of isolates $K 5^{\top}, 237-4^{\top}$ and 215-51 are AY660685, $A Y 444822$ and $A Y 444823$, and those for the gyrB sequences obtained in this study are DQ143914-DQ143928 and CP000082. marine environments including Antarctic sea ice, ornithogenic soil and sediments, the stomach contents of the Antarctic krill Euphausia, seawater (north-western Pacific Ocean, $300 \mathrm{~m}$ depth), the deep sea and the internal tissues of a marine ascidian (Bowman et al., 1997; Maruyama et al., 2000; Romanenko et al., 2002; Yumoto et al., 2003); other sources of Psychrobacter include pigeon faeces, fish, poultry, dairy products, fermented seafood, clinical sources and an infected lamb (Gonzalez et al., 2000; Juni \& Heym, 1986; Kämpfer et al., 2002; Vela et al., 2003; Yoon et al., 2003).

Here, we report the characterization of three Psychrobacter isolates from Arctic permafrost (Bakermans et al., 2003; Vishnivetskaya et al., 2000). The taxonomic position of these isolates was established through a polyphasic approach utilizing phenotypic, genotypic, chemotaxonomic and phylogenetic analyses. These analyses led to the description of two novel species.

The three isolates were recovered from permafrost samples within the Kolyma lowland region of Siberia; in this area, the 
permafrost is continuous, approximately $800 \mathrm{~m}$ thick and, at depth, remains stable at -9 to $-11{ }^{\circ} \mathrm{C}$ (Gilichinsky et al., 1992; Shi et al., 1997). Isolates $273-4^{\mathrm{T}}$ and 215-51 were recovered from borehole $1 / 97$ cores at depths of 12.5 and $13.0 \mathrm{~m}$, respectively, from a 20000 - to 30000 -year-old sandy loam within a 15-20 m late Pleistocene icy complex (Vishnivetskaya et al., 2000). This complex froze as it was deposited and has remained frozen to modern times (Sher, 1974). In this region, the deposition rate of sediments is $1-2 \mathrm{~mm}$ per year; therefore, a $0.5 \mathrm{~m}$ difference in the depths of these samples implies a difference in time of deposition of 250 to 500 years. Isolate $\mathrm{K} 5^{\mathrm{T}}$ was recovered from a cryopeg [a highly saline ( $13 \%)$ lens of water] intersected by borehole $16 / 99$ at a depth of $11 \mathrm{~m}$ within a marine layer of the permafrost that was deposited beneath shallow lagoons at temperatures slightly above $0{ }^{\circ} \mathrm{C}$ and froze subaerially as the polar ocean regressed 110000 to 112000 years ago (Bakermans et al., 2003; Gilichinsky et al., 2003, 2005).

The isolates were non-motile, Gram-negative coccobacilli; diploid forms were common. Strains formed non-pigmented, circular, smooth, opaque colonies with a diameter of $\sim 2 \mathrm{~mm}$ when grown on marine agar (MA) (Bowman, 2005). Cells were approximately $0.5 \times 1.5 \mu \mathrm{m}$ (width by length) in size. The $\mathrm{pH}$ range, salt tolerance and sodium requirement of the isolates were tested as described previously, except that the experiments were conducted in broth cultures and verified via three successive transfers of a 1:1000 dilution of inoculum into fresh medium (Bozal et al., 2003). Isolate $\mathrm{K}^{\mathrm{T}}$ was able to grow at $\mathrm{pH}$ values ranging from 6 to $9 \cdot 5$; while isolates $273-4^{\mathrm{T}}$ and $215-51$ only grew at $\mathrm{pH} 7-9$. Isolates $\mathrm{K}^{\mathrm{T}}, 273-4^{\mathrm{T}}$ and $215-51$ tolerated high concentrations of $\mathrm{NaCl}$, respectively growing in $1 \cdot 7$, 1.3 and $1.3 \mathrm{M} \mathrm{NaCl}$. Psychrobacter species typically tolerate high salt concentrations, from 1 to $2 \cdot 6 \mathrm{M}$ (Bowman, 2005). $\mathrm{Na}^{+}$was not required for the growth of isolate $\mathrm{K}^{\mathrm{T}}$; however, $\mathrm{Na}^{+}$was required at concentrations of 10 and $5 \mathrm{mM}$, respectively, for the growth of isolates $273-4^{\mathrm{T}}$ and $215-51$. The majority of described Psychrobacter species grow in the absence of $\mathrm{Na}^{+}$; however, $P$. frigidicola, Psychrobacter glacincola and Psychrobacter pacificensis grow weakly in the absence of $\mathrm{Na}^{+}$, while Psychrobacter fozii, Psychrobacter marincola and Psychrobacter submarinus do not grow at all (Bowman, 2005).

The physiological and biochemical properties of the isolates and 13 previously described Psychrobacter species were determined (Table 1). API strips 20NE and ZYM (bioMérieux Vitek) were used according to the manufacturer's instructions except that incubation was carried out at $20{ }^{\circ} \mathrm{C}$ for 48 and $20 \mathrm{~h}$, respectively, and that strips were inoculated with cells grown on MA for 3 days at $20^{\circ} \mathrm{C}$. While all of the isolates and species had similar patterns of response on the API strips, no two patterns were identical. Clustering of API test results did not yield significant differences from trees constructed using the 16S rRNA gene sequence (data not shown). Isolates $\mathrm{K} 5^{\mathrm{T}}$ and $273-4^{\mathrm{T}}$ did not have phenotypes identical to any of the described
Psychrobacter species, suggesting that they represent distinct species. The phenotypes of isolates $273-4^{\mathrm{T}}$ and $215-51$ varied from each other only in reduction of nitrate to nitrite, indicating that these two isolates may be members of the same species. Variability in the ability to reduce nitrate within and between species of Psychrobacter is common (Bowman, 2005).

The growth temperature ranges of isolates $\mathrm{K}^{\mathrm{T}}$ and $273-4^{\mathrm{T}}$ were -10 to $30^{\circ} \mathrm{C}$ and -10 to $28^{\circ} \mathrm{C}$, respectively (growth at -10 and $28^{\circ} \mathrm{C}$ was established in broth cultures). The growth temperature range of the isolates was compared with those of described Psychrobacter species by spotting $10 \mu \mathrm{l}$ of $10^{-1}, 10^{-2}, 10^{-3}$ and $10^{-4}$ dilutions of 3-day cultures grown at $20^{\circ} \mathrm{C}$ onto MA and incubating at 37, 30, $20, \sim 4,0$ and $-5^{\circ} \mathrm{C}$. Growth was considered possible only if the highest dilution showed growth by colony formation. While Psychrobacter species are not routinely tested for growth at temperatures below $0{ }^{\circ} \mathrm{C}$, we demonstrated that, similar to our isolates, most species are capable of growth on MA at $-5{ }^{\circ} \mathrm{C}$ (Table 1). The low-temperature limit for growth remains to be determined for many of these species.

The phospholipid fatty acid (PLFA) composition of membranes was determined using standard methods (Navarrete et al., 2000; Ponder et al., 2005). The profile of isolate $\mathrm{K} 5^{\mathrm{T}}$ was dominated by the monoenoic PLFAs $18: 1 \omega 7 c$ ( $58 \pm$ $11 \%)$ and $16: 1 \omega 7 c(31 \pm 10 \%)$, with $18: 0$ as a minor component $(\sim 7 \%)$. The PLFA profile of isolate $273-4^{\mathrm{T}}$ was dominated by the saturated PLFAs $18: 0(44 \cdot 2 \pm 0 \cdot 5 \%)$ and $16: 0(28 \cdot 3 \pm 0 \cdot 5 \%)$; however, in the presence of salt or low temperatures, the PLFA composition shifted to unsaturated PLFAs 18:1 and 16:1 (Ponder et al., 2005). Both isolates had PLFA profiles similar to, but distinct from, all other Psychrobacter species, which predominantly contain the monoenoic PLFAs $18: 1 \omega 9 c(30-84 \%)$ and $16: 1 \omega 7 c$ (3-53\%) (Bowman, 2005).

Phylogenetic analysis of the 16S rRNA gene sequence confirmed the placement of isolates $\mathrm{K} 5^{\mathrm{T}}, 273-4^{\mathrm{T}}$ and $215-51$ in the genus Psychrobacter. The $16 \mathrm{~S}$ rRNA gene was amplified by PCR and sequenced as described previously (Reysenbach et al., 1994; Suzuki \& Giovannoni, 1996). Sequence reads were assembled using PHREP and CONSED (Gordon, 2004). Consensus 16S rRNA gene sequences and the most similar sequences from GenBank identified by BLAST searches were aligned against the most similar sequences in the Ribosomal Database Project II release 8.0 database (Maidak et al., 2001) using the fast align procedure of the ARB software package (Ludwig et al., 2004). Alignments were corrected manually by taking into account primary and secondary structure considerations and ambiguously aligned regions were removed from the analysis. Phylogenetic trees were constructed using the following methods: Fitch-Margoliash distance method implemented in the FITCH program of the PHYLIP package (Felsenstein, 2004), maximum-likelihood method implemented in the fastDNAmL program (Olsen et al., 1994) and parsimony analysis as implemented in the PAUP 4.0 program. 
Table 1. Physiological characteristics of the novel isolates and type strains of Psychrobacter species

Reference strains: 1, P. faecalis DSM $14664^{\mathrm{T}} ; 2$, P. fozii LMG $21280^{\mathrm{T}} ; 3$, P. frigidicola DSM $12411^{\mathrm{T}} ; 4$, P. glacincola ATCC $700754^{\mathrm{T}}$; 5, P. immobilis ATCC $43116^{\mathrm{T}} ; 6$, P. jeotgali JCM $11463^{\mathrm{T}} ; 7$, P. luti LMG $21276^{\mathrm{T}} ; 8$, P. marincola DSM $14160^{\mathrm{T}} ; 9$, P. okhotskensis JCM $11840^{\mathrm{T}}$; 10 , P. pacificensis IFO $16270^{\mathrm{T}}$; 11 , P. proteolyticus DSM $13887^{\mathrm{T}} ; 12$, P. submarinus DSM $14161^{\mathrm{T}} ; 13$, P. urativorans ATCC $15174^{\mathrm{T}}$. ++ , Strongly positive; +, positive; (+), weakly positive; -, negative; ND, no data. All strains were positive for esterase (C4), esterase lipase (C8), leucine arylamidase, naphthol-AS-BI-phosphohydrolase and cytochrome oxidase. All strains were negative for trypsin, $\alpha$-chymotrypsin, $\alpha$-galactosidase, $\beta$-glucuronidase, $\alpha$-glucosidase, $\beta$-glucosidase, $N$-acetyl- $\beta$-glucosaminidase, $\alpha$-mannosidase, $\mathrm{N}_{2}$ production from nitrates, tryptophanase (indole production), fermentation, arginine dihydrolase, protease (gelatin hydrolysis) and $\beta$-galactosidase. All strains were also negative for assimilation of D-glucose, D-mannose, D-mannitol, $\mathrm{N}$-acetylglucosamine, D-maltose, potassium gluconate, capric acid, adipic acid and phenylacetic acid. All data were obtained in this study.

\begin{tabular}{|c|c|c|c|c|c|c|c|c|c|c|c|c|c|c|c|c|}
\hline Test & $215-51$ & $273-4^{T}$ & $\mathrm{~K} 5^{\mathrm{T}}$ & 1 & 2 & 3 & 4 & 5 & 6 & 7 & 8 & 9 & 10 & 11 & 12 & 13 \\
\hline \multicolumn{17}{|l|}{ Presence of: } \\
\hline Alkaline phosphatase & + & ++ & + & + & ++ & - & + & ++ & + & + & + & ++ & + & ++ & ++ & + \\
\hline Valine arylamidase & + & + & - & + & + & - & + & + & - & - & + & - & + & + & + & - \\
\hline Cysteine arylamidase & - & - & - & - & + & + & + & - & + & - & + & - & + & - & + & - \\
\hline$\alpha$-Fucosidase & - & - & - & + & - & - & - & - & - & - & - & - & - & - & - & - \\
\hline Urease & - & - & - & - & $(+)$ & - & - & - & + & - & - & - & - & - & - & $(+)$ \\
\hline$\beta$-Glucosidase & - & - & - & - & - & - & - & - & + & + & - & - & - & - & - & $(+)$ \\
\hline Reduction of nitrate to nitrite & - & + & - & + & - & - & + & + & + & + & - & - & - & - & - & - \\
\hline \multicolumn{17}{|l|}{ Assimilation of: } \\
\hline$-5^{\circ} \mathrm{C}$ & $\mathrm{ND}$ & + & + & - & + & $\mathrm{ND}$ & + & + & - & + & - & + & - & + & - & + \\
\hline $0^{\circ} \mathrm{C}$ & $\mathrm{ND}$ & + & + & + & + & $\mathrm{ND}$ & + & + & + & + & - & + & - & + & - & + \\
\hline $30^{\circ} \mathrm{C}$ & ND & - & + & + & + & $\mathrm{ND}$ & - & + & + & + & + & + & + & + & + & - \\
\hline $37^{\circ} \mathrm{C}$ & $\mathrm{ND}$ & - & - & + & - & $\mathrm{ND}$ & - & - & - & - & - & - & - & - & - & - \\
\hline
\end{tabular}

${ }^{\star}$ Growth was tested on MA at 37, 30, $20 \sim 4,0$ and $-5^{\circ} \mathrm{C}$ as described in the text. All strains grew at $\sim 4$ and $20^{\circ} \mathrm{C}$.

$16 \mathrm{~S}$ rRNA gene trees clearly demonstrated that isolates $\mathrm{K}^{\mathrm{T}}$, 273-4 $4^{\mathrm{T}}$ and 215-51 were members of the genus Psychrobacter (Fig. 1a). The high nucleotide sequence identity of isolates $273-4^{\mathrm{T}}$ and $215-51(99 \cdot 8 \%$ nucleotide identity) suggests that these isolates may be strains of the same species. Isolates 273-4 ${ }^{\mathrm{T}}$ and 215-51 formed a cluster with Psychrobacter luti, P. okhotskensis and P. fozii, all species that have been isolated from cold marine waters or sediments (Bozal et al., 2003; Yumoto et al., 2003). Interestingly, many of the species clustered according to growth temperature range, whether by the low-temperature or high-temperature limit. For example, Psychrobacter faecalis, Psychrobacter jeotgali, $P$. marincola and $P$. submarinus have low-temperature growth limits at $0-4{ }^{\circ} \mathrm{C}$ and high-temperature growth limits at 35$37^{\circ} \mathrm{C}$ and form a cluster of species in $16 \mathrm{~S}$ rRNA gene trees (bootstrap values of 87-100\%). Psychrobacter urativorans, P. glacincola and P. frigidicola do not grow above $27^{\circ} \mathrm{C}$ and cluster together (bootstrap values of 67 and $72 \%$ ). These associations support the hypothesis that there are definitive genomic and molecular differences between species that lead to differences in growth temperature ranges. While monophyletic groups could be identified within the $16 \mathrm{~S}$ rRNA gene tree, the low bootstrap values (25-72\%) and the lack of reproducibility in tree topologies when different tree algorithms were used (data not shown) indicated that the resolution of the 16S rRNA gene was not high enough to generate a reliable phylogenetic tree of closely related species (Fox et al., 1992; Stackebrandt \& Goebel, 1994).

To define better the phylogenetic relationships between Psychrobacter species, analyses were performed with nearly full-length sequences of gyrB. To design primers targeting conserved regions of the gyrB gene, nucleotide sequences from complete genome sequences of Coxiella burnetii RSA 493 (GenBank accession no. NC_002971), Xanthomonas campestris pv. campestris ATCC 33913 ${ }^{\mathrm{T}}$ (NC_003902), Xanthomonas axonopodis pv. citri 306 (NC_003919), Xylella fastidiosa 9a5c (NC_002488), Xylella fastidiosa Temecula1 (NC_004556) and isolate 273-4 ${ }^{\mathrm{T}}$ (CP000082) were translated in ARB and their corresponding amino acid 


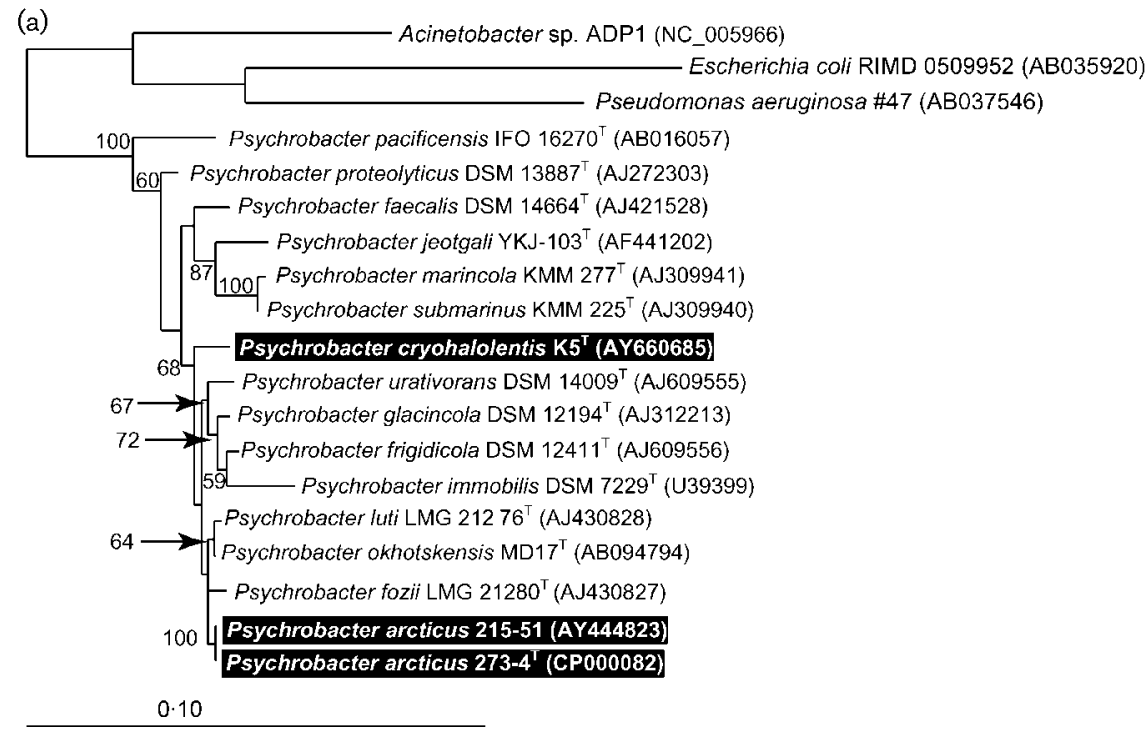

(b)

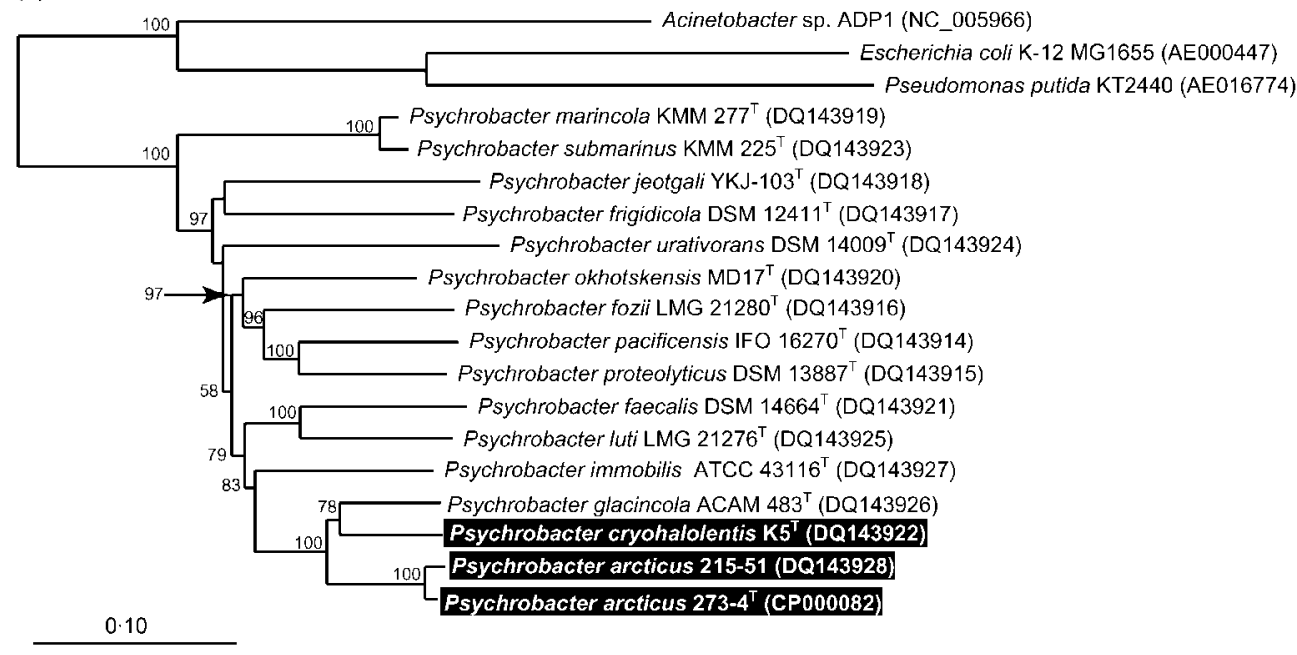

Fig. 1. Fitch-Margoliash phylogenetic trees of $16 \mathrm{~S}$ rRNA (a) and gyrB (b) gene sequences. Isolate sequences are highlighted. Bars, 0.1 base substitutions per nucleotide position. Numbers at nodes represent numbers of 100 bootstrap values that were greater than $50 \%$.

sequences were aligned using the T-COFFEE program (Notredame et al., 2000). Primers were designed by the Probe Design tool of the ARB package and modified by visual inspection. The gyrB gene was amplified using PCR in $50 \mu \mathrm{l}$ reactions containing 50-100 ng genomic DNA, $2.5 \mathrm{mM}$ $\mathrm{MgCl}_{2}$, 50 pmol each primer [147-FD1 (5'-RWRCGYCCHGGVATGTAYAT) and 2421-RD (5'-TTCATYTCRCCTARVCCYTT)], $1 \times$ PCR buffer (Promega), $200 \mu \mathrm{M}$ each dNTP, $0 \cdot 2 \mathrm{mg} \mathrm{BSA} \mathrm{ml}^{-1}$ (New England Biolabs) and $2 \cdot 5 \mathrm{U}$ Taq polymerase (Promega). The following touchdown thermal profile was used for incubation: $95^{\circ} \mathrm{C}$ for $5 \mathrm{~min} ; 10$ cycles at $95{ }^{\circ} \mathrm{C}$ for $45 \mathrm{~s}, 55 \cdot 5^{\circ} \mathrm{C}$ (minus $0.5^{\circ} \mathrm{C}$ per cycle) for $50 \mathrm{~s}$ and $72^{\circ} \mathrm{C}$ for $3 \mathrm{~min} ; 28$ cycles at $95^{\circ} \mathrm{C}$ for $45 \mathrm{~s}, 54^{\circ} \mathrm{C}$ for $50 \mathrm{~s}$ and $72{ }^{\circ} \mathrm{C}$ for $3 \mathrm{~min}$; and a final extension at $72{ }^{\circ} \mathrm{C}$ for $7 \mathrm{~min}$. The $\sim 2 \cdot 2 \mathrm{kbp}$ PCR products were concentrated and gel-purified prior to sequencing by the GTSF, MSU, using primers 147-FD1, 2421-RD, 480F (5'-ATGAATATCTGGCGTGAAGG)， 474R (5'-CGCCAGATATTCATCTCAAG), 704F (5'-TGAGCGTATTGATAAGCGTC), 1500R (5' -TCAGGCGTTTGACGGAAGAA) and 2040R (5'-GGTTGCGGTGCATGGATATT). Sequences were assembled and trees constructed as described above.

As anticipated, the gyrB gene tree had a different topology from the 16S rRNA gene tree (Fig. 1b) (Yamamoto \& Harayama, 1996). For example, P. faecalis and P. jeotgali no longer formed a cluster with each other or with $P$. submarinus and P. marincola. Isolates $273-4^{\mathrm{T}}$ and $215-51$ 
still formed a cluster in gyrB trees, but their closest relatives were now isolate $\mathrm{K}^{\mathrm{T}}$ and $P$. glacincola, relationships that were supported by DNA-DNA hybridization data (see below). The high bootstrap values (48-100\%; 9 of the 13 nodes had bootstrap values greater than $96 \%$ ) and reproducibility of tree topologies using three different phylogeny reconstruction methods (data not shown) indicated that gyrB is a better phylogenetic marker for establishing phylogenetic relationships between Psychrobacter species than the $16 \mathrm{~S}$ rRNA gene.

To examine the DNA relatedness of isolates to each other and to previously described Psychrobacter species on a broader scale, whole genome DNA-DNA hybridizations were performed. Genomic DNA was prepared from cells grown at $20^{\circ} \mathrm{C}$ using the Qiagen Genomic DNA kit with 500/G Genomic-tips (Qiagen). DNA fixation, probe preparation and quadruplicate reciprocal hybridization was performed in microplates with a hybridization temperature of $37^{\circ} \mathrm{C}$ (Ezaki et al., 1989). All three isolates had DNA-DNA relatedness values of $50 \%$ or less with other described Psychrobacter species (Fig. 2). Isolates $273-4^{\mathrm{T}}$ and 215-51 can be considered to belong to the same species as their DNA was $89 \%$ related, while isolate $\mathrm{K}^{\mathrm{T}}$ had 64 and $50 \%$ relatedness with $273-4^{\mathrm{T}}$ and $215-51$, respectively. These data demonstrate that isolate $\mathrm{K}^{\mathrm{T}}$ and isolate $273-4^{\mathrm{T}}$ represent distinct species of Psychrobacter, as their DNADNA relatedness values fall well below the $70 \%$ similarity cut-off recommended to define a species (Wayne et al., 1987).

Additional analyses were possible due to the availability of whole genome sequences for isolates $\mathrm{K} 5^{\mathrm{T}}$ and $273-4^{\mathrm{T}}$. The average nucleotide identity (ANI) of all conserved

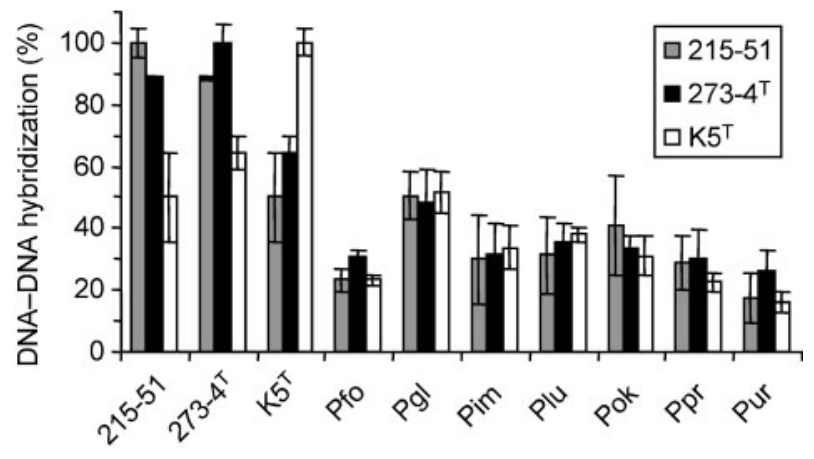

Fig. 2. Comparison of DNA-DNA hybridization of isolates with various Psychrobacter species. Error bars indicate the standard deviation of values for reciprocal hybridizations in triplicate. Abbreviations: Pfo, P. fozii LMG 21280'; Pgl, P. glacincola ATCC $700754^{\top}$; Pim, Psychrobacter immobilis ATCC $43116^{\top}$; Plu, P. luti LMG 21276'; Pok, P. okhotskensis JCM 11840'; Ppr, Psychrobacter proteolyticus DSM $13887^{\top}$; Pur, P. urativorans ATCC $15174^{\top}$. genes between the two isolates was calculated to be $88 \%$ (Konstantinidis \& Tiedje, 2005). Based on the current standard for species description, DNA-DNA reassociation values of $70 \%$ correspond to an ANI of about $94-95 \%$; for example, the ANI between Escherichia coli and Salmonella spp. genomes is $\sim 80 \%$ (Konstantinidis \& Tiedje, 2005). Thus, by this definition, the two isolates can also be considered to represent distinct species.

Isolates K5 ${ }^{\mathrm{T}}, 273-4^{\mathrm{T}}$ and $215-51$ belong in the genus Psychrobacter based on physiological and phenotypic features detailed in the original description (Juni \& Heym, 1986) and based on phylogenetic analyses. They are halotolerant, psychrotolerant, aerobic, non-motile, Gram-negative, nonpigmented, oxidase-positive coccobacilli that are unable to grow at temperatures above $30^{\circ} \mathrm{C}$. Phylogenetically, these isolates were most closely related to $P$. glacincola. Phenotypic, genotypic, chemotaxonomic and phylogenetic analyses demonstrated that isolates $273-4^{\mathrm{T}}$ and $215-51$ were strains of the same species $\left(273-4^{\mathrm{T}}\right.$ was designated the type strain). However, DNA-DNA hybridization studies demonstrated that isolates $\mathrm{K} 5^{\mathrm{T}}$ and $273-4^{\mathrm{T}}$ were members of distinct species with relatedness values to previously described species of Psychrobacter well below $70 \%$ (Wayne et al., 1987). Thus, isolates $\mathrm{K}^{\mathrm{T}}$ and $273-4^{\mathrm{T}}$ form two unique taxa within the genus Psychrobacter and it is proposed that the new groups are named Psychrobacter cryohalolentis sp. nov. and Psychrobacter arcticus sp. nov., respectively.

\section{Description of Psychrobacter cryohalolentis sp. nov.}

Psychrobacter cryohalolentis (cry.o.ha.lo.len'tis. Gr. n. kryos ice, Gr. n. hals salt, L. gen. fem. n. lentis from a lens; N.L. gen. fem. n. cryohalolentis from a frozen salt lens).

Cells are Gram-negative, non-motile, non-pigmented, nonspore-forming coccobacilli, $0 \cdot 9-1 \cdot 3 \mu \mathrm{m}$ long and $0 \cdot 5-$ $0 \cdot 8 \mu \mathrm{m}$ wide. Growth occurs at -10 to $30^{\circ} \mathrm{C}$. Optimal growth temperature is $22^{\circ} \mathrm{C}$. Colonies on MA are about $2 \mathrm{~mm}$ in diameter, smooth, opaque and circular after 5 days at $20^{\circ} \mathrm{C}$. NaCl is not required for growth, but growth occurs in $1.7 \mathrm{M} \mathrm{NaCl}$. Strictly aerobic; oxidase test is positive. Acid is not produced from carbohydrates. Cells are not able to reduce nitrate to nitrite. Urease and tryptophan deaminase are not produced. Positive in the following biochemical tests: alkaline phosphatase, esterase ( $\mathrm{C} 4)$, esterase lipase (C8), lipase (C14), leucine arylamidase and naphthol-ASBI-phosphohydrolase. Negative for hydrolysis of casein. Growth occurs on citrate, lactate, acetate and L-glutamic acid. Cells can reduce Tweens 40 and 80 . The main cellular fatty acids are $18: 1 \omega 7 c$ and $16: 1 \omega 7 c$. The $\mathrm{G}+\mathrm{C}$ content of DNA of the type strain is $42 \cdot 3 \mathrm{~mol} \%$. Genome size is $\sim 3 \cdot 1 \mathrm{Mb}$.

The type strain, strain $\mathrm{K}^{\mathrm{T}} \quad\left(=\mathrm{DSM} \quad 17306^{\mathrm{T}}=\mathrm{VKM}\right.$ $\mathrm{B}-2378^{\mathrm{T}}$ ), was isolated from a cryopeg within permafrost in the Kolyma lowland, Siberia, Russia. 


\section{Description of Psychrobacter arcticus sp. nov.}

Psychrobacter arcticus (arc'tic.us. L. masc. adj. arcticus northern, Arctic).

Cells are Gram-negative, non-motile, non-pigmented, non-spore-forming coccobacilli, $1.62 \pm 0.13 \mu \mathrm{m}$ long and $0.73 \pm 0.03 \mu \mathrm{m}$ wide. Growth occurs at -10 to $28^{\circ} \mathrm{C}$. Optimal growth temperature is $22^{\circ} \mathrm{C}$. Colonies on MA are about $2 \mathrm{~mm}$ in diameter, smooth, opaque and circular after 5 days at $20^{\circ} \mathrm{C}$. At least $10 \mathrm{mM} \mathrm{NaCl}$ is required for growth. Growth can occur in $1.25 \mathrm{M} \mathrm{NaCl}$. Strictly aerobic; oxidase and catalase tests are positive. Acid is not produced from carbohydrates. Strains variably reduce nitrate to nitrite (type strain is positive). Urease and tryptophan deaminase are not produced. Positive in the following biochemical tests: alkaline phosphatase, esterase (C4), esterase lipase (C8), valine arylamidase, acid phosphatase, leucine arylamidase and naphthol-AS-BI-phosphohydrolase. Negative for hydrolysis of casein. Growth occurs on lactate, acetate, glutamate, pyruvate, butyrate and leucine. Cells can reduce Tweens 40 and 80 . The main cellular fatty acids are 18:0 and 16:0 (or 18:1 and 16:1 at low temperatures or high salt concentrations). The $\mathrm{G}+\mathrm{C}$ content of DNA is $42 \cdot 7 \mathrm{~mol} \%$. Genome size is $2 \cdot 6 \mathrm{Mb}$.

The type strain, strain $273-4^{\mathrm{T}}\left(=\mathrm{DSM} \quad 17307^{\mathrm{T}}=\mathrm{VKM}\right.$ $\left.\mathrm{B}-2377^{\mathrm{T}}\right)$, was isolated from permafrost sediment cores in the Kolyma lowland, Siberia, Russia.

\section{Acknowledgements}

Funding was provided through membership in the NASA Astrobiology Institute. Fatty acid analysis for isolate $\mathrm{K} 5^{\mathrm{T}}$ was provided by A. Peacock and D. White, Tennessee State University. Genome size and $\mathrm{G}+\mathrm{C}$ content was determined from genome sequence data produced by the US Department of Energy Joint Genome Institute (http:// www.jgi.doe.gov/).

\section{References}

Bakermans, C., Tsapin, A. I., Souza-Egipsy, V., Gilichinsky, D. A. \& Nealson, K. H. (2003). Reproduction and metabolism at $-10{ }^{\circ} \mathrm{C}$ of bacteria isolated from Siberian permafrost. Environ Microbiol 5, 321-326.

Bowman, J. P. (2005). The genus Psychrobacter. In The Prokaryotes: an Evolving Electronic Resource for the Microbiological Community. Edited by M. Dworkin. New York: Springer. http://link.springer-ny. com/link/service/books/10125/

Bowman, J., Nichols, D. \& McMeekin, T. (1997). Psychrobacter glacincola sp. nov, a halotolerant, psychrophilic bacterium isolated from Antarctic sea ice. Syst Appl Microbiol 20, 209-215.

Bozal, N., Montes, M. J., Tudela, E. \& Guinea, J. (2003). Characterization of several Psychrobacter strains isolated from Antarctic environments and description of Psychrobacter luti sp. nov. and Psychrobacter fozii sp. nov. Int J Syst Evol Microbiol 53, 1093-1100.

Ezaki, T., Hashimoto, Y. \& Yabuuchi, E. (1989). Fluorometric deoxyribonucleic acid-deoxyribonucleic acid hybridization in microdilution wells as an alternative to membrane-filter hybridization in which radioisotopes are used to determine the genetic relatedness among bacterial strains. Int J Syst Bacteriol 39, 224-229.
Felsenstein, J. (2004). PHYLIP - Phylogeny Inference Package, version 3.6. Distributed by the author. University of Washington, Seattle, USA.

Fox, G. E., Wisotzkey, J. D. \& Jurtshuk, P., Jr (1992). How close is close: $16 \mathrm{~S}$ rRNA sequence identity may not be sufficient to guarantee species identity. Int J Syst Bacteriol 42, 166-170.

Gilichinsky, D., Vorobyova, E. A., Erokhina, L. G., Fedorov-Davydov, D. G. \& Chaikovskaya, N. R. (1992). Long-term preservation of microbial ecosystems in permafrost. Adv Space Res 12, 255-263.

Gilichinsky, D., Rivkina, E., Shcherbakova, V., Laurinavichuis, K. \& Tiedje, J. (2003). Supercooled water brines within permafrost - an unknown ecological niche for microorganisms: a model for astrobiology. Astrobiology 3, 331-341.

Gilichinsky, D., Rivkina, E., Bakermans, C. \& 9 other authors (2005). Biodiversity of cryopegs in permafrost. FEMS Microbiol Ecol 53, 117-128.

Gonzalez, C. J., Santos, J. A., Garcia-Lopez, M. L. \& Otero, A. (2000). Psychrobacters and related bacteria in freshwater fish. J Food Prot 63, 315-321.

Gordon, D. (2004). Viewing and editing assembled sequences using Consed. In Current Protocols in Bioinformatics, pp. 11.12.11-11.12.43. Edited by A. D. Baxevanis \& D. B. Davison. New York: Wiley.

Juni, E. \& Heym, G. A. (1986). Psychrobacter immobilis gen. nov., sp. nov.: genospecies composed of gram-negative, aerobic, oxidasepositive coccobacilli. Int J Syst Bacteriol 36, 388-391.

Kämpfer, P., Albrecht, A., Buczolits, S. \& Busse, H.-J. (2002). Psychrobacter faecalis sp. nov., a new species from a bioaerosol originating from pigeon faeces. Syst Appl Microbiol 25, 31-36.

Konstantinidis, K. T. \& Tiedje, J. M. (2005). Genomic insights that advance the species definition for prokaryotes. Proc Natl Acad Sci U S A 102, 2567-2572.

Ludwig, W., Strunk, O., Westram, R. \& 29 other authors (2004). ARB: a software environment for sequence data. Nucleic Acids Res 32, 1363-1371.

Maidak, B. L., Cole, J. R., Lilburn, T. G. \& 7 other authors (2001). The RDP-II (Ribosomal Database Project). Nucleic Acids Res 29, 173-174.

Maruyama, A., Honda, D., Yamamoto, K., Kitamura, K. \& Higashihara, T. (2000). Phylogenetic analysis of psychrophilic bacteria isolated from the Japan Trench, including a description of the deep-sea species Psychrobacter pacificensis sp. nov. Int J Syst Evol Microbiol 50, 835-846.

Moss, C. W., Wallace, P. L., Hollis, D. G. \& Weaver, R. E. (1988). Cultural and chemical characterization of CDC groups EO-2, M-5, and M-6, Moraxella (Moraxella) species, Oligella urethralis, Acinetobacter species, and Psychrobacter immobilis. J Clin Microbiol 26, 484-492.

Navarrete, A., Peacock, A., Macnaughton, S. J., Urmeneta, J., Mas-Castellà, J., White, D. C. \& Guerrero, R. (2000). Physiological status and community composition of microbial mats of the Ebro Delta, Spain, by signature lipid biomarkers. Microb Ecol 39, 92-99.

Notredame, C., Higgins, D. \& Heringa, J. (2000). T-Coffee: a novel method for fast and accurate multiple sequence alignment. J Mol Biol 302, 205-217.

Olsen, G. J., Matsuda, H., Hagström, R. \& Overbeek, R. (1994). fastDNAmL: a tool for construction of phylogenetic trees of DNA sequences using maximum likelihood. Comput Appl Biosci 10, 41-48.

Ponder, M. A., Gilmour, S. J., Bergholz, P. W., Mindock, C. A., Hollingsworth, R., Thomashow, M. F. \& Tiedje, J. M. (2005). Characterization of potential stress responses in ancient Siberian permafrost psychroactive bacteria. FEMS Microbiol Ecol 53, 103-115. 
Reysenbach, A. L., Wickham, G. S. \& Pace, N. R. (1994). Phylogenetic analysis of the hyperthermophilic pink filament community in Octopus Spring, Yellowstone National Park. Appl Environ Microbiol 60, 2113-2119.

Romanenko, L. A., Schumann, P., Rohde, M., Lysenko, A. M., Mikhailov, V. V. \& Stackebrandt, E. (2002). Psychrobacter submarinus sp. nov. and Psychrobacter marincola sp. nov., psychrophilic halophiles from marine environments. Int J Syst Evol Microbiol 52, 1291-1297.

Sher, A. V. (1974). Pleistocene mammals and stratigraphy of the Far Northeast USSR and North America. Int Geol Rev 16, $1-282$.

Shi, T., Reeves, R. H., Gilichinsky, D. A. \& Friedmann, E. I. (1997). Characterization of viable bacteria from Siberian permafrost by $16 \mathrm{~S}$ rDNA sequencing. Microb Ecol 33, 169-179.

Stackebrandt, E. \& Goebel, B. (1994). Taxonomic note: a place for DNA-DNA reassociation and $16 \mathrm{~S}$ rRNA sequence analysis in the present species definition in bacteriology. Int J Syst Bacteriol 44, 846-849.

Suzuki, M. T. \& Giovannoni, S. J. (1996). Bias caused by template annealing in the amplification of mixtures of $16 \mathrm{~S}$ rRNA genes by PCR. Appl Environ Microbiol 62, 625-630.
Vela, A. I., Collins, M. D., Latre, M. V., Mateos, A., Moreno, M. A., Hutson, R., Dominguez, L. \& Fernandez-Garayzabal, J. F. (2003). Psychrobacter pulmonis sp. nov., isolated from the lungs of lambs. Int J Syst Evol Microbiol 53, 415-419.

Vishnivetskaya, T., Kathariou, S., McGrath, J., Gilichinsky, D. \& Tiedje, J. M. (2000). Low-temperature recovery strategies for the isolation of bacteria from ancient permafrost sediments. Extremophiles 4, 165-173.

Wayne, L. G., Brenner, D. J., Colwell, R. R. \& 9 other authors (1987). Report of the ad hoc committee on reconciliation of approaches to bacterial systematics. Int J Syst Bacteriol 37, 463-464.

Yamamoto, S. \& Harayama, S. (1996). Phylogenetic analysis of Acinetobacter strains based on the nucleotide sequences of gyrB genes and on the amino acid sequences of their products. Int $J$ Syst Bacteriol 46, 506-511.

Yoon, J.-H., Kang, K. H. \& Park, Y.-H. (2003). Psychrobacter jeotgali sp. nov., isolated from jeotgal, a traditional Korean fermented seafood. Int J Syst Evol Microbiol 53, 449-454.

Yumoto, I., Hirota, K., Sogabe, Y., Nodasaka, Y., Yokota, Y. \& Hoshino, T. (2003). Psychrobacter okhotskensis sp. nov., a lipaseproducing facultative psychrophile isolated from the coast of the Okhotsk Sea. Int J Syst Evol Microbiol 53, 1985-1989. 